\title{
Fen Bilgisi Öğretmen Adaylarının Mobil Teknolojilerin Laboratuvar Ortamında Kullanılmasına Yönelik Görüşlerinin Değerlendirilmesi* Murat OKUR**
}

Öz: Bu araştırmanın amacı, fen bilgisi öğretmen adaylarının laboratuvar ortamlarında mobil teknolojileri kullanmasına yönelik görüşlerinin değerlendirilmesidir. Araştırmada yöntem olarak özel durum çalışması seçilmiştir. Araştırmanın örneklemini uygulamaya katılan 32 öğretmen adayı içerisinden basit rastgele örneklem yöntemine göre ve gönüllülük esasına göre seçilen 10 öğretmen adayı oluşturmaktadır. Bu bağlamda Genel Fizik Laboratuvarı II dersi kapsamında mobil teknolojik aletlerin tanıtılmasına, kullanılmasına ve veri alınmasına yönelik 4 haftalık hizmet içi eğitim verilerek yapılandırmacı kuramın 5E modeline uygun olarak geliştirilen 6 farklı etkinlik hazırlanarak uygulanmıştır. Uygulamalar sonunda veri toplama aracı olarak geliştirilen yarı yapılandırılmış mülakat formu ile veriler toplanmıştır. Elde edilen veriler betimsel ve içerik analizinden faydalanılarak tablolar halinde sergilenmiştir. Araştırmanın sonunda, mobil teknolojik aletlerin laboratuvar ortamında kullanılmasının zamandan tasarruf sağlaması ve daha güvenli veriler sunması gibi avantajları, öğrencileri hazırcılığa teşvik etmesi ve kurulumunun zaman alması gibi dezavantajların olduğu görülmüştür. Ayrıca mobil teknolojik aletlerin taşınabilir olmasından dolayı laboratuvar dışı ortamlarda deneylerin yapılabilmesi ve diğer laboratuvar dersleri içinde etkinliklerin geliştirilmesi önerilerinde bulunulmuştur.

Anahtar Kelimeler: Mobil teknolojiyle bütünleşik sensörler, öğretmen adayı görüşleri. mobil teknoloji, fizik laboratuvarı, 5E modeli

\footnotetext{
* Bu çalışma, 2017 Uluslarası Eğitim Teknolojileri Sempozyumunda sözlü bildiri olarak sunulmuştır. Bu çalışma doktora tezinden türetilmiştir.

**Dr.Öğretim Üyesi, Sivas Cumhuriyet Üniversitesi, Eğitim Fakültesi, Temel Eğitim Bölümü, Sınıf Eğitimi Anabilim Dalı, Email: okurmurat55@hotmail.com, ORCID No: 0000-0003-2502-2276.
} 


\section{Evaluation of Pre-Service Science Teachers' Opinions on the Use of Mobile Technologies in Laboratory Environment}

Abstract: The aim of this study is to evaluate pre-service science teachers' opinions about the use of mobile technologies in laboratory environments. In the research, a case study was chosen as a method. The sample of the research consists of 10 pre-service teachers selected according to the simple random sampling method and on a voluntary basis among 32 pre-service teachers participating in the application. In this context, General Physics Laboratory II course, 6 different activities developed in accordance with the 5E model of the constructivist theory were prepared and applied by giving 4-week training according to the approach of developing technical skills for the introduction, use and data acquisition of mobile technological devices. At the end of the applications, data were collected with a semi-structured interview form developed as a data collection tool. The obtained data were presented in tables using descriptive and content analysis. At the end of the study, it has been seen that the use of mobile technological devices in the laboratory environment has advantages such as saving time and providing safer data, and disadvantages such as encouraging students to prepare and taking time to set up. In addition, due to the portability of mobile technological devices, suggestions were made to conduct experiments in non-laboratory environments and to develop activities in other laboratory courses.

Keywords: Sensors integrated with mobile technology, pre-service teacher opinions, mobile technology, physics laboratory, 5E model

\section{Giriş}

İnsanlığın başlangıcından beri toplumsal yaşamı etkileyen en önemli unsurlardan birisi teknoloji olmuştur. Bir ülkenin teknolojik gelişimi sağlaması noktasında teknolojinin üretilmesi ve kullanılması konusunda izleyeceği politikaların önemi büyüktür (Avc1, Kurtoğlu ve Seferoğlu, 2010). Günümüzde teknolojik gelişmelere paralel olarak ülkeler milli eğitim politikalarında köklü değişikliklere giderek eğitim ve öğretimin içerisinde daha çok teknolojinin kullanılmasına önem vermeye başlamışlardır (Akınoğlu, 2005). Nitekim yapılan araştırmalar, eğitim-öğretim içerisinde teknolojinin kullanılmasının öğrencilerinin motivasyonunun artırılması ve kalıcı öğrenmenin sağlanması konusunda etkili olduğu sonucunu ortaya koymuştur (Bakırcı ve Kutlu, 2018). Eğitim ve öğretim içerisinde kara tahta ve tebeşir kullanılmasından günümüze kadar birçok değişiklikler meydana gelmiştir. Bir 
zamanlar tepegözlerin eğitiminde kullanılması çok ilgi çekici bulunurken daha sonraları slaytların, video filmlerin ve bilgisayarların kullanılması ile bu cazibe ortadan kalkmaya başlamıştır. Bugüne gelindiğinde ise sınıflarda akıllı tahtaların kullanıldığı derslerin simülasyonlar ve animasyonlar gibi bilgisayar yazılımları ile desteklendiği öğrenmeyi kolaylaştıran soyut kavramların somutlaştırılarak zihinde canlandırılmasını yardımcı olan ders ortamları karşımıza çıkmaktadır (Okur, 2014).

Ülkelerin bilim ve teknolojide ilerleyebilmeleri araştırıcı, sorgulayıcı, analitik düşünebilen ve girişimci bireyler yetiştirebilmesine bağlıdır. Bu özelliklere sahip bireylerin yetiştirilebilmesi de fen bilimlerinin öğretilmesi ile daha kolay ve etkili olarak gerçekleştirilebilecektir. Fen bilimleri öğretimi sürecinde ise yaparak, yaşayarak öğrenmelerin sağlandığı ortamlar laboratuvarlardır (Ayvacı ve Küçük, 2005). Fen Bilgisi eğitiminde öğrencilerin fenne karşı ilgisinin artırılması, konuların etkili ve kalıcı bir şekilde öğretilmesi için laboratuvar uygulamalarına büyük önem verilmesi gerekir (Güneş, Şener, Germi ve Can, 2013). Ülkemiz de dünyadaki bu değişime paralel olarak fen laboratuvarlarını teknolojik aletlerle yenileme çabası içerisindedir. Kara tahta, tebeşir ve geleneksel deney aletleri ile donatılmış laboratuvarlar zamanla yerini, akıllı tahtalar, modern deney üniteleri ve deney setlerine bırakmaya başlamıştır. MEB, Fırsatları Artırma ve Teknolojiyi İyileştirme Hareketi (FATİH) projesi kapsamında her sınıf ve laboratuvar ortamını akıllı tahtalar, bilgisayarlar, projeksiyon cihazları ve yerel ağ bağlantıları ile donatmayı hedeflemektedir (Ayvacı, Bakırcı ve Başak, 2014). Ayrıca MEB okullarındaki laboratuvar ortamlarının zenginleştirilmesi ve teknolojinin geldiği son noktayı yakalamak için ilköğretim ve ortaöğretim fen laboratuvarlarında kullanılmak üzere mobil teknolojik aletler ve sensörlerin (NOVA 5000 gibi) alımını gerçekleştirmiştir (Güngör Seyhan ve Okur, 2020). Bu teknolojik aletler laboratuvar ortamında kullanıldı̆̆ı gibi mobil özelliği sayesinde laboratuvar dışında da aktif olarak kullanılması ile birlikte doğadaki sıcaklık, nem, gün 1şığı, karbondioksit değişimi gibi verileri kaydedip eş zamanlı grafiklerini çizme gibi özelliklere de sahiptir. Teknolojik aletlerin fen laboratuvar ortamlarında kullanılmasının fizik ve kimya gibi soyut kavramların öğretiminde, öğrencilere bilimsel becerilerin kazandırılması açısından yararlıdır (Özdener, 2005).

Bütün bu teknolojik deney araç gereçlerin MEB bünyesindeki okullara alımının yanında bu aletlerin etkili kullanılması da büyük önem arz etmektedir. Yenilenen laboratuvar ortamlarında bulunan aletlerin öğretimde etkili bir şekilde kullanılması, öğretmenlerin bu aletleri tanımaları ve kullanmak için gerekli becerileri kazanmaları ile mümkün olacaktır. $\mathrm{Bu}$ çalışma fen ve teknoloji öğretmen adaylarına yönelik, mobil teknolojik aletlere bütünleşik 
sistemlerin tanıtılması, özelliklerin öğrenilmesi, deney düzeneklerinin kurulması, deney programı ile verilerin alınması ve kaydedilmesi gibi etkinlikleri içermesinden dolayı önemlidir. Öğretmen adaylarının bu teknolojilerin kullanımını öğrenmeleri ileride de bu teknolojik cihazları sınıflarında etkili şekilde kullanabilme becerilerine sahip olmaları açısından ve laboratuvar çalışmalarına karşı olumlu tutum geliştirmeleri açısından büyük önem taşımaktadır.

Laboratuvar yaklaşımları genel anlamda kapalı ve açık uçlu olmak üzere ikiye ayrılmaktadır. Kapalı uçlu yaklaşım doğrulayıcı laboratuvar yaklaşımı olarak da bilinmekte olup tümdengelim ilkesine dayanmaktadır. Tümevarım ilkesine dayalı açık uçlu laboratuvar yaklaşımı ise, öğrencilerin aktif olduğu yaparak yaşayarak öğrenme felsefesine dayanmaktadır. $\mathrm{Bu}$ yaklaşım öğrencilerin bilgiye keşfederek ulaşmasını temel aldığından yapılandırmacı kurama uygun bir yaklaşım olarak bilinmektedir. Bu yaklaşımlardan sıkça kullanılanları buluş, keşfedici ve bütünleştirici laboratuvar yaklaşımlarıdır (Çepni ve Ayvacı, 2006). Son yıllarda yapılan çalışmalar incelendiğinde yapılandırmacı kuramın 5E modelini temel alan laboratuvar uygulamalarına rastlanmaktadır (Ayvacı ve Yıldız, 2013; Açışlı ve Turgut, 2012; Bal, 2011).

Laboratuvar uygulamalarına yönelik ilgili literatür incelendiğinde, son yıllarda yapılan çalışmaların laboratuvar ortamlarında teknolojinin kullanılmasına yönelik olduğu görülmektedir (Ayvacı, Özsevgeç ve Aydın, 2004; Çalık, Artun ve Küçük, 2013; Okur, 2014). Çalışmalarda, doğrulayıcı laboratuvar yaklaşımı ile açık uçlu uygulanan laboratuvar yaklaşımının etkililiğinin araştırılması amaçlanmadır (Aydın vd., 2012; Özdener, 2005; Sönmez, vd., 2005; Tanel ve Önder, 2010). Teknoloji kullanılan bu çalışmalarda, dijital veri kaydediciler, sensörler, animasyonlar ve simülasyonlar, hazır paket programların kullanıldığı görülmektedir. Yapılandırmacı felsefeyi temel alarak teknolojinin entegre edildiği laboratuvar ortamlarında olumlu sonuçların alındığı bir çok araştırmacı tarafından ifade edilmektedir (Ambrose, 2004; Borghi, De Ambrosis, Lunati ve Mascheretti, 2001; Pinto', Ferna'ndez, Oro ve Aliberas, 2004; Russell, Lucas ve McRobbie, 2004).

Yapılan çalışma kapsamında, yapılandırmacı kuramın 5E modeline göre mobil teknolojik aletler ile bütünleşik sensörlerin kullanılması ile geliştirilen 6 farklı çalışma yaprakları kullanılarak 6 hafta boyunca uygulanmıştır. Uygulamalar sonunda öğretmen adaylarından mobil teknolojik aletlerin laboratuvar ortamlarında kullanılmasına yönelik mülakatlar yürütülerek görüşlerinin alınması amaçlamıştır. Bu bağlamda, örneklem gurubuna aşağıdaki sorular yöneltilmiştir. Buna göre; 
1. Mobil teknoloji ile bütünleşik sensörler ile yapılan laboratuvar uygulamalarının avantajları ve dezavantajları hakkındaki görüşleriniz nelerdir? Açıklayınız?

2. Mobil teknoloji ile bütünleşik sensörler ile laboratuvar uygulamaları yaparken ne gibi sorunlar ile karşılaştınız? Açıklayınız?

3. Mobil teknoloji ile bütünleşik sensörler ile laboratuvar uygulamalarının yürütülmesi fen kavramlarının öğretimine nasıl bir katkı yapar? Açıklayınız?

4. Mobil teknoloji ile bütünleşik sensörler ile laboratuvar uygulamasında daha iyi yürütülmesi için ne gibi önerileriniz olur? Açıklayınız?

\section{Yöntem}

\section{Araştırma Deseni}

$\mathrm{Bu}$ araştırmada nitel araştırma yöntemlerinden özel durum çalışması kullanılmıştır. Özel durum yönteminin en belirgin özelliği, araştırmacı tarafından belirlenen konu üzerinde ön yargılara sahip olmadan derinlemesine inceleme yapılmasıdır (Ekiz, 2020). Durum çalışması var olan durumu ortaya koyan bir araştırma yöntemi olarak bilinmektedir (Çepni, 2018). Bu araştırmada da öğretmen adaylarının uygulama sonunda mobil teknolojilerin laboratuvar ortamında kullanılması sonucu edindikleri tecrübelerin ortaya konulması açısından özel durum yöntemi tercih edilmiştir.

\section{Çalışma Grubu}

Araştırma Karadeniz Teknik Üniversitesi Fatih Eğitim Fakültesi Fen Bilgisi Öğretmenliğinde öğrenim gören Genel Fizik Laboratuvarı II dersini alan 32 öğretmen adayı ile yürütülmüştür. Araştırmada uygulamaya katılan örneklem grubu basit rastgele örneklem seçimine göre belirlenirken yarı yapılandırılmış mülakatların yapıldığı örneklem grubunda ise nitel örneklem yöntemlerinden kolay ulaşılabilir örneklem yöntemi seçilmiştir. Bu örnekleme yöntemi araştırmaya pratiklik kazandırılmak için ulaşılabilir en yakın örneklemin seçilmesi ilkesine dayanmaktadır (Yıldırım ve Şimşek, 2013). Buna göre uygulamalar sonunda kolay ulaşılabilir 10 öğretmen adayı ile yarı yapılandırılmış mülakatlar yapılmıştır. Analiz sürecinde katılımc1lar MÖ1, MÖ2, MÖ3, MÖ4, MÖ5, MÖ6, MÖ7, MÖ8, MÖ9, MÖ10 şeklinde kodlanmıştır.

\section{Veri Toplama Araçları ve Analizi}


Araştırma verileri yarı yapılandırılmış mülakat formu kullanılarak elde edilmiştir. Bu bağlamda öğretmen adaylarının görüşlerini belirlemek için 5 sorudan oluşan yarı yapılandırılmış mülakat soruları hazırlanmıştır. Mülakat soruları ile uygulamanın öğretmen adaylarına sağladığı avantaj ve dezavantajlar, uygulama sürecinde yaşanan sorunlar, uygulamaların fen eğitimine sağladığı katkılar ve daha iyi bir uygulama için öğretmen adaylarının önerileri sorgulanmıştır. Hazırlanan sorular, uzman tarafından incelenerek geçerlilik çalışması yapılmıştır. Yarı yapılandırılmış mülakat sorularının pilot çalışması, geliştirilen rehber materyallerin pilot çalışmasından sonra çalışmaya katılan öğretmen adaylarına uygulanarak görüşleri alınmıştır. Pilot çalışma sonunda öğretmen adaylarının verdiği cevaplar transkript edilip yakın anlam taşıyan (avantaj ve dezavantajlar) iki soru birleştirilerek tek soru haline getirilmiştir. Pilot uygulama sonrasında son hali 4 sorudan oluşan mülakat formu hazırlanmıştır. Pilot çalışma sonucunda öğretmen adaylarına yürütülen her mülakat için yaklaşık 20 dakikalık sürenin verilmesinin yeterli olacağı tespit edilmiştir. Yarı yapılandırılmış mülakatlarda, sorulacak sorular önceden hazırlanır fakat mülakatın gidişatına göre sorular yeniden düzenlenebilir. Bu durum, araştırmacıya mülakat esnasında sorular hakkında ayrıntılı şekilde açıklayabilme olanağı sağlamasından dolayı kolaylık ve avantajlar sağlamaktadır (Çepni, 2018; Ekiz, 2020). Ayrıca yarı yapılandırılmış mülakatın amacı açık uçlu sorular ile katılımcının bakış açısını anlayabilmektir. Araştırmacı katılımcıyla arasında bir uyum yaratmaya çalışarak mülakat karşılıklı sohbet tarzında yürütülür (Yıldırım ve Şimşek, 2013).

Mülakatların analizinde, betimsel ve içerik analizinden yararlanılmıştır. İçerik analizi, belirli bir kurala dayalı olarak oluşturulan kodlamalarla elde edilen verilerin daha küçük içerik kategorileri ile özetlendiği sistematik bir tekniktir (Büyüköztürk, 2007). Mülakatlar sonucunda elde edilen ses kayıtları transkript edilmiştir. Transkript sonucunda kodlar çıkarılarak kategoriler oluşturulmuştur. Elde edilen bulgular matris şeklinde sergilenmiştir. Matrisler oluşturulurken elde edilen kodlar numaralandırılmıştır. Buna göre mülakatın birinci sorusu için mobil teknolojik aletlerin avantajları A harfi ile kodlandırılmıştır. Mobil teknolojik aletin dezavantajları ise D harfi ile kodlandırılmıştır. Mülakatın ikinci sorusunda, uygulamada yaşanan sorunlar için S harfi kod olarak kullanılmıştır. Mülakatın üçüncü sorusu için, mobil teknolojik aletin fen eğitimine katkıları $\mathrm{K}$ harfi ile kodlandırılmıştır. Mülakatın dördüncü sorusu için, mobil teknolojik aletin uygulamalarının daha iyi yapılmasına yönelik öneriler $P$ harfi ile kodlandırılmıştır. 


\section{Etik Kurul Kararı}

Çalışma, araştırmacının 2014 yılında Karadeniz Teknik Ümiversitesi Eğitim Bilimleri Enstitüsü Fen Bilgisi Eğitimi bilim dalında yapmış olduğu “Mobil teknolojilerin laboratuvar ortamlarında kullanılmasına yönelik rehber materyallerin geliştirilmesi ve etkililiğinin değerlendirilmesi: Genel fizik laboratuart-II örneği” isimli doktora tezinden türetilmiştir.

\section{Bulgular}

\section{Yarı Yapılandırılmış Mülakatın Birinci Sorusuna Yönelik Bulgular}

Mülakatın birinci sorusunda öğretmen adaylarına "Mobil teknoloji ile bütünleşik sensörler ile yapılan laboratuvar uygulamalarının avantaj ve dezavantajları hakkında neler düşünmektesiniz? Açıklayınız?” sorusu yöneltilmiştir. Bu soru için öğretmen adaylarının vermiş oldukları cevaplar neticesinde sistemin avantajları ve dezavantajları şeklinde, çıkartılan kodlar ve öğretmen adaylarının vermiş olduklarını örnek cevaplar ile Tablo 1 ve Tablo 2'de sunulmuştur.

Tablo 1. Mülakatın Birinci Sorusuna “Avantajları” Şeklinde Verilen Öğretmen Adaylarının Cevapları ve Frekansları

\begin{tabular}{|c|c|c|c|c|}
\hline \multirow{2}{*}{$\begin{array}{c}\text { Kod } \\
\text { No }\end{array}$} & Avantajlar & \multirow{2}{*}{ Katılımcılar } & \multirow{2}{*}{$\mathrm{f}$} & \multirow{2}{*}{ Alıntı } \\
\hline & Kod & & & \\
\hline A1 & $\begin{array}{l}\text { Zamandan tasarruf } \\
\text { sağlaması }\end{array}$ & $\begin{array}{c}\text { MÖ1,M Ö2, } \\
\text { MÖ3, MÖ4, } \\
\text { MÖ5, MÖ6, } \\
\text { MÖ7, } \\
\text { MÖ8,MÖ9, } \\
\text { MÖ10 }\end{array}$ & 10 & $\begin{array}{l}\text { “...NOVA } 5000 \text { sayesinde deney sonuçlarına } \\
\text { çok daha kısa sürede ulaşabiliyoruz. Böylece } \\
\text { deney verileri ve değişkenleri üzerinde daha } \\
\text { fazla tartışma olanağl bulabiliyoruz...” (MÖ3). } \\
\text { “...Deneylerimizi çok daha hizlı } \\
\text { gerçekleştirerek, tekrar tekrar deneyi } \\
\text { yapabilme ve deney düzeneğindeki } \\
\text { değişkenleri fark edebilme imkânımız } \\
\text { oluyor...” (MÖ8). } \\
\text { “...Deney sonuçlarına çok klsada } \\
\text { ulaşabiliyoruz. Bu sonuçları istediğimizde } \\
\text { grafiklendirip grafikleri yorumlayabilme } \\
\text { zamanı buluyoruz...(MÖ10). }\end{array}$ \\
\hline A2 & $\begin{array}{l}\text { Daha güvenli verilere } \\
\text { ulaşma imkânı sunması }\end{array}$ & $\begin{array}{c}\text { MÖ1, MÖ2, } \\
\text { MÖ3, MÖ4, } \\
\text { MÖ5, MÖ6, } \\
\text { MÖ7, } \\
\text { MÖ8,MÖ9, } \\
\text { MÖ10 }\end{array}$ & 10 & $\begin{array}{l}\text { “...Nova } 5000 \text { deney seti ile deneylerde } \\
\text { aldı̆̆ımız değerler çok hassastı. Bu değerlerin } \\
\text { güvenilir olduğu grafiklerin doğru çıkmass ile } \\
\text { ispatlanıyordu. Çok küçük değerler bile } \\
\text { kaydediyor...” (MÖ5) } \\
\text { “...Deney sırasında aldığımız verilerin güvenli } \\
\text { olduğunu çizdiğimiz grafikler sonucunda } \\
\text { gördük. Mesela } 10 \text { ohm'luk bir direnç ile } \\
\text { ölçümler aldık. Sistemin çizdiği gerilim akım } \\
\text { grafiğinin eğimi bize } 10 \text { ohm'a yakın bir değer }\end{array}$ \\
\hline
\end{tabular}




\begin{tabular}{|c|c|c|c|c|}
\hline & & & & $\begin{array}{l}\text { gösterdi. Bundan dolayı doğru sonuçlar elde } \\
\text { ettik...” (MÖ7) }\end{array}$ \\
\hline A3 & $\begin{array}{l}\text { Görsel veriler (grafik, } \\
\text { tablo, şema vb.) } \\
\text { sunarak öğrenmeyi } \\
\text { hızlandırması }\end{array}$ & $\begin{array}{c}\text { MÖ1, MÖ2, } \\
\text { MÖ3, MÖ4, } \\
\text { MÖ5, MÖ6, } \\
\text { MÖ7, } \\
\text { MÖ8,MÖ9, } \\
\text { MÖ10 }\end{array}$ & 10 & $\begin{array}{l}\text { “...Deney yaparken verilerin otomatik olarak } \\
\text { tablo halinde alınması ve aynı zamanda } \\
\text { grafiklerinin çizilmesi çok faydalı oldu. Ayrıca } \\
\text { grafiklerin üzerinde ölçüm değerlerini } \\
\text { görmemiz deneyi anlamamızl kolaylaştırdı...” } \\
\text { (MÖ2) } \\
\text { “...Deneylerin bu sistemle yapılıp verilerin } \\
\text { bilgisayar ortamında elde edilmesinin } \\
\text { deneylerin pekiştirilmesi açısından ve bilginin } \\
\text { öğrenilmesi açısıdan faydalı olacağını } \\
\text { düşünüyorum...” (MÖ6) }\end{array}$ \\
\hline A4 & $\begin{array}{l}\text { Verilerin kaydedilmesi } \\
\text { (arşivleme ve e- } \\
\text { portfolyo) }\end{array}$ & $\begin{array}{l}\text { MÖ5, MÖ6, } \\
\text { MÖ8, MÖ9, } \\
\text { MÖ10 }\end{array}$ & 5 & $\begin{array}{l}\text { “...Bize verilen sistemde deneylere başlarken } \\
\text { grubumuz için bir klasör oluşturduk. Her hafta } \\
\text { yaptı̆̆ımı deneylerin sonuçlarını kaydetmemiz } \\
\text { istenmişti. Bu şekilde önceki haftalarda } \\
\text { yaptığımız bir deneyin sonuçlarına tekrar } \\
\text { ulaşma imkanı bulduk...” (MÖ6) } \\
\text { “..Bu sistemin deneyde aldığımız sonuçları } \\
\text { kaydetmesi deney süresini kısalttı. Tekrar } \\
\text { verileri kaydetmek için zaman harcamadık...” } \\
\text { (MÖ9) }\end{array}$ \\
\hline A5 & Motivasyonu arttırmas 1 & $\begin{array}{l}\text { MÖ1, MÖ4, } \\
\text { MÖ6, MÖ8 }\end{array}$ & 4 & $\begin{array}{l}\text { “...Teknolojik aletler ile yani bilgisayarlı } \\
\text { sistemler ve sensörler ile deney yapmak çok } \\
\text { ilgilimi çekti. Veriler alınırken grafiğin nasıl } \\
\text { çıkacağını merak ettim...” (MÖ4) } \\
\text { “...Nova } 5000 \text { ile deney yapmak çok eğlenceli } \\
\text { öğretmen olduğumda böyle bir imkânın } \\
\text { olmasını çok isterim. Çünkü bu zamane } \\
\text { çocukları bilgisayarlı teknolojik aletlere çok } \\
\text { ilgili ögrenirken motivasyonlarının } \\
\text { artıracağını düşünüyorum. Benim bile } \\
\text { motivasyonum arttı açıçası...” (MÖ6) }\end{array}$ \\
\hline A6 & Hata oranını azaltması & $\begin{array}{c}\text { MÖ1, MÖ2, } \\
\text { MÖ3, MÖ4, } \\
\text { MÖ5, MÖ6, } \\
\text { MÖ7, } \\
\text { MÖ8,MÖ9, } \\
\text { MÖ10 }\end{array}$ & 10 & $\begin{array}{l}\text { “...Elde ettiğimiz verilerin çok hassas olması } \\
\text { deneydeki yapacă̆ımı hataları çok aza } \\
\text { indirmekte...” (MÖ2) } \\
\text { “...Özellikle ohm kanunu ve transformatör } \\
\text { deneyinde dikkatimi çekti elde edilen veriler ile } \\
\text { olması gereken sonuçlar birbirine çok yakındı } \\
\text { bu da hata oranının az olduğunu gösterdi..." } \\
\text { (MÖ7) }\end{array}$ \\
\hline A7 & $\begin{array}{l}\text { Sistemin mobil } \\
\text { (taşınabilir) olması }\end{array}$ & $\begin{array}{c}\text { MÖ1, MÖ2, } \\
\text { MÖ3, MÖ4, } \\
\text { MÖ5, MÖ6, } \\
\text { MÖ7, } \\
\text { MÖ8,MÖ9, } \\
\text { MÖ10 }\end{array}$ & 10 & $\begin{array}{l}\text { “...Biz Nova } 5000 \text { ile deneyleri laboratuvar } \\
\text { ortamında yaptık ama bu sistemin sokakta bile } \\
\text { deney yapmamıza imkân tanıması bence en } \\
\text { önemli avantajıdır...” (MÖ4) } \\
\text { “...Nova } 5000 \text { cihazı şarjlı olduğundan dolayı } \\
\text { uzun bir süre güç kaynağına ihtiyaç duymadan } \\
\text { kullanılabiliyor. Aynı zaman sensörlerinin } \\
\text { sistemle birlikte çallşması ölçüm alırken başka } \\
\text { bir şeye ihtiyaç kalmıyor. Mesela elimizde } \\
\text { başka sensörlerde olsa doğa ile ilgili birçok } \\
\text { deneyi dışarda bile yapabiliriz...” (MÖ10) }\end{array}$ \\
\hline A8 & $\begin{array}{l}\text { Teknolojinin ders } \\
\text { sürecine } \\
\text { entegrasyonunun } \\
\text { sağlanması }\end{array}$ & $\begin{array}{l}\text { MÖ3, MÖ4, } \\
\text { MÖ6, MÖ7, } \\
\text { MÖ9, MÖ10 }\end{array}$ & 6 & $\begin{array}{l}\text { “...Nova } 5000 \text { işletim sistemi olarak Windows } \\
\text { işletim sistemini kullanıyor. Deney yaparken } \\
\text { sadece sensörler ile veri almadık. } \\
\text { Simulasyonlar ve sunum dosyaların da dersin } \\
\text { içerisinde kullanabildik, özellikle }\end{array}$ \\
\hline
\end{tabular}




simülasyonların kullanılması benim çok ilgimi
çekmişti...” (MÖ7)
“...Deneylerin sadece eski aletler ile yapılması
bence çok sıkıcı. Böyle teknolojik aletler ile
deney yapmak ve çocukların teknoloji ders
ortamında kullanması bence günümüz çağında
çok faydalı olacağını düşünüyorum...” (MÖ9)

Tablo 1'e göre öğretmen adaylarının mobil teknoloji ile bütünleşik sensörler ile yapılan laboratuvar uygulamalarının avantajları hakkında görüşleri incelendiğinde, "Zamandan tasarruf sağlaması (A1), Daha güvenli verilere ulaşma imkânı sunması (A2), Görsel veriler (grafik, tablo, şema vb.) sunarak öğrenmeyi hızlandırması (A3), Verilerin kaydedilmesi (arşivleme ve e-portfolyo) (A4), Motivasyonu arttırması (A5), Hata oranını azaltması (A6), Sistemin mobil (taşınabilir) olması (A7), Teknolojinin ders sürecine entegrasyonunun sağlanması (A8), Deneylerin daha eğlenceli hale gelmesi (A9), Sistemin web destekli uygulamalara imkân tanıması (A10)" kodlarının oluştuğu görülmektedir. İlgili kodlara ait frekans değerleri incelendiğinde, A1, A2, A3, A6 ve A7 kodlar1 10 öğretmen aday1 tarafindan ifade edilirken, A10 kodu 8 öğretmen adayı tarafindan, A9 kodu 7 öğretmen adayı tarafından, A8 kodu 6 öğretmen adayı tarafından, A4 kodu 5 öğretmen adayı tarafindan ve A5 kodu ise 4 öğretmen adayı tarafından ifade edilmiştir.

Tablo 2. Mülakatın Birinci Sorusuna “Dezavantajları” Şeklinde Verilen Öğretmen Adaylarının Cevapları ve Frekansları

\begin{tabular}{|c|c|c|c|c|}
\hline \multirow{2}{*}{$\begin{array}{c}\text { Kod } \\
\text { No }\end{array}$} & Dezavantajlar & \multirow{2}{*}{ Katılımcilar } & \multirow{2}{*}{$\mathrm{f}$} & \multirow{2}{*}{ Alint } \\
\hline & Kod & & & \\
\hline D1 & Dezavantaj1 yoktur. & $\begin{array}{c}\text { MÖ2, MÖ4, } \\
\text { MÖ6, MÖ8, } \\
\text { MÖ10 }\end{array}$ & 5 & $\begin{array}{l}\text { “...Sistemin herhangi bir dezavantajı olduğunu } \\
\text { düşünmüyorum...” (MÖ2). } \\
\text { “...Nova 5000 deney sistemleri ile yapmış } \\
\text { olduğumuz deneylerde gayet sağllklı sonuçlar } \\
\text { aldık, ayrıca internete bağlanması sayesinde } \\
\text { simülasyolar izledik bence bir dezavantajı } \\
\text { yoktu...” (MO6) }\end{array}$ \\
\hline D2 & $\begin{array}{l}\text { Öğrencileri hazırcılığa } \\
\text { teşvik etmesi }\end{array}$ & $\begin{array}{l}\text { MÖ1, MÖ3, } \\
\text { MÖ5, MÖ7, } \\
\text { MÖ9 }\end{array}$ & 5 & $\begin{array}{l}\text { “...Deney verilerinin sistem tarafindan } \\
\text { otomatik olarak kaydedilip grafik ve tablolar } \\
\text { şeklinde sunuluyor olması öğrencileri } \\
\text { hazırcılığa itebilir...” (MÖ5). } \\
\text { “...Sistemin verileri bize hazır olarak vermesi } \\
\text { ve bizim bu verileri yazll olarak } \\
\text { kaydetmememiz kalıcı ögrenmemizi } \\
\text { engelleyebilir. Ayrıa grafik çizme becerimizi } \\
\text { kullanmadığımıziçin bir eksiklik olabilir. Ama } \\
\text { hazır grafikleri de yorulmamızda etkili } \\
\text { olabilir...”(MÖ9). }\end{array}$ \\
\hline D3 & Sensörlerin hassasiyeti & MÖ3, MÖ5 & 2 & $\begin{array}{llrr}\text { “...Deney yaparken } & \text { NOVA } & \text { 5000'in } \\
\text { sensörlerinin çok hassas olmast nedeniyle dlş }\end{array}$ \\
\hline
\end{tabular}




\begin{tabular}{|c|c|c|c|c|}
\hline & & & & $\begin{array}{l}\text { etkenlerden kismen etkilenebileceğini } \\
\text { düşünüyorum. Bazen verilerin küçük } \\
\text { değerlerde olsa sapmalar gösterdiğini ve } \\
\text { gruplar arasında farklı değerlerin oluşmasına } \\
\text { neden olduğunu düş̧ӥnüyorum..." (MÖ5) }\end{array}$ \\
\hline D4 & $\begin{array}{l}\text { Kurulumunun zaman } \\
\text { alması }\end{array}$ & MÖ7 & 1 & $\begin{array}{l}\text { “...Normal deney malzemelerinin kurulumuna } \\
\text { ilaveten NOVA 5000'in kurulumu ve sensör } \\
\text { ayarları için de zaman harcanması deneyi } \\
\text { uzatabilir..." (MÖ7). }\end{array}$ \\
\hline
\end{tabular}

Tablo 2'ye göre öğretmen adaylarının mobil teknoloji ile bütünleşik sensörler ile yapılan laboratuvar uygulamalarının dezavantajları hakkında görüşleri incelendiğinde, “Dezavantajı yoktur (D1), Öğrencileri hazırcılığa teşvik etmesi (D2), Sensörlerin hassasiyeti (D3), Kurulumunun zaman alması (D4)" kodlarının oluştuğu görülmektedir. İlgili kodlara ait frekans değerleri incelendiğinde D1 ve D2 kodları 5 öğretmen adayı tarafından ifade edilirken, D3 kodu 2 öğretmen adayı tarafından ve D4 kodu ise 1 öğretmen adayı tarafindan ifade edilmiştir.

\section{Yarı Yapılandırılmış Mülakatın İkinci Sorusuna Yönelik Bulgular}

Mülakatın ikinci sorusunda öğretmen adaylarına "Mobil teknoloji ile bütünleşik sensörler ile yapılan laboratuvar uygulamaları yaparken yaşadığınız sorunlar var mı? Varsa ne gibi sorunlar yaşadınız? Açıklayınız?” sorusu yöneltilmiştir. Öğretmen adaylarının vermiş olduklarını örnek cevaplar Tablo 3'de sunulmuştur.

Tablo 3. Mülakatın İkinci Sorusuna Verilen Öğretmen Adaylarının Cevaplar ve Frekanslar

\begin{tabular}{|c|c|c|c|c|}
\hline \multirow{2}{*}{$\begin{array}{l}\text { Kod } \\
\text { No }\end{array}$} & Yaşanan Sorunlar & \multirow[t]{2}{*}{ Katılımcilar } & \multirow[t]{2}{*}{$\mathrm{f}$} & \multirow[t]{2}{*}{ Alınt1 } \\
\hline & Kod & & & \\
\hline S1 & $\begin{array}{l}\text { Hiçbir } \\
\text { yaşamadım. }\end{array}$ & $\begin{array}{l}\text { MÖ2, MÖ6, } \\
\text { MÖ10 }\end{array}$ & 3 & $\begin{array}{l}\text { “...Ders sürecinde herhangi bir sorun } \\
\text { yaşamadım...”(MÖ10). } \\
\text { “...Nova } 5000 \text { kullanımı ile ilgili olarak dönem } \\
\text { başında kullanımına yönelik kurslara katıldım. } \\
\text { Deney öncesi sensörlerin kullanımı ve veri } \\
\text { alınmasını ögrendim. Bundan dolayı deneyleri } \\
\text { yaparken hiçbir sorunla karşılaşmadım...” } \\
\text { (MÖ2). }\end{array}$ \\
\hline S2 & $\begin{array}{l}\text { Sistemi kullanabilme } \\
\text { becerisinden } \\
\text { kaynaklanan sorunlar }\end{array}$ & $\begin{array}{l}\text { MÖ1, MÖ3, } \\
\text { MÖ8, MÖ9 }\end{array}$ & 4 & $\begin{array}{l}\text { “...ilk haftalarda sistemi henüz yeni tanıdı̆̆ım } \\
\text { için her ne kadar tanıtım kurslarına katılsak da } \\
\text { sorunlar yaşadım. Sensör ayarlarını yaparken } \\
\text { ve grafiklerin koordinat sistemlerini } \\
\text { oluştururken zorlanıyordum. Sistemi tanıdıkça } \\
\text { uyum sağlamaya başladım..” (MÖ1). } \\
\text { “...Sistemin tanıtım kursuna geç katıldım. O } \\
\text { nedenle sistemi tam ögrenemeden deneylere }\end{array}$ \\
\hline
\end{tabular}




\begin{tabular}{|c|c|c|c|c|}
\hline & & & & $\begin{array}{l}\text { başladım ama zamanla öğrendim ve verileri } \\
\text { sağlıklı bir şekilde alabildim...” (MÖ3). } \\
\text { “...Dokunmatik kalemleri kullanırken sorunlar } \\
\text { yaşadım...”(MÖ8). }\end{array}$ \\
\hline S3 & $\begin{array}{ll}\text { Güç } & \text { kaynağı } \\
\text { kullanımında } & \text { yaşanan } \\
\text { sorunlar } & \end{array}$ & MÖ5, MÖ7 & 2 & $\begin{array}{l}\text { “...Deneylerin büyük kısmında pil bataryaları } \\
\text { yardımıla veri aldık. Ancak } 102 \text { deneyde güç } \\
\text { kaynăg kullanırken, güç kaynă̆ının şehir } \\
\text { şebekesinden gelen elektrik voltajının farklılığ } \\
\text { nedeniyle NOVA 5000'de okunan değer ile güç } \\
\text { kaynağındaki değer arasında farklılılar } \\
\text { oldu...” (MÖ5). } \\
\text { “...Normal deneyleri güç kaynağl ile } \\
\text { yaptığımızda doğru akım değerleri alternatif } \\
\begin{array}{l}\text { akımmış gibi gözüküyordu. Bu nedenle pil ve } \\
\text { pil bataryaları kullandık...” (MÖ7) }\end{array}\end{array}$ \\
\hline S4 & $\begin{array}{l}\text { Cihaz } \\
\text { yetersizliği }\end{array}$ & $\begin{array}{l}\text { MÖ1,MÖ3, } \\
\text { MÖ5, MÖ7, } \\
\text { MÖ9 }\end{array}$ & 5 & $\begin{array}{l}\text { “...Deney gruplarının kalabalık olması cihaz } \\
\text { sayısının az olmasından dolayı cihazı } \\
\text { sahiplenen arkadaş Nova } 5000 \text { ile daha çok } \\
\text { haşır neşir oldu. Keşke imkân olsa da gruplar } \\
\text { en çok } 203 \text { kişi olsaydı ya da daha çok alet } \\
\text { olsaydı...” (MÖ5) } \\
\text { “...Bireysel olarak yada iki kişi deney yapmak } \\
\text { bu sistemlerde bence daha iyi olurdu. Çünkü } \\
\text { bazı arkadaşlar sadece izlemek zorunda kaldı. } \\
\text { Aleti kullanmak bence deneyi daha anlaşıllı } \\
\text { hale getirirdi. Bence bu yaşanan en temel } \\
\text { sorundu galiba...” (MÖ7) }\end{array}$ \\
\hline S5 & $\begin{array}{l}\text { Grup çalışmalarından } \\
\text { kaynaklanan sorunlar }\end{array}$ & MÖ4, MÖ7, & 2 & $\begin{array}{l}\text { “...Grup çallşması yaparken herkes cihazı } \\
\text { kullanmak istedi böyle olunca cihazı } \\
\text { kullanmayanlar deney yaparken sıkıldılar. } \\
\text { Bazen önemli bir noktayı kaçırabiliyorsunuz. } \\
\text { Aslında bu sorun birazda grup çallşmasındaki } \\
\text { görevlendirmelerden kaynaklanıyordu } \\
\text { sanırım...” (MÖ4) }\end{array}$ \\
\hline S6 & Teknik sorunlar & $\begin{array}{l}\text { MO1, MÖ8, } \\
\text { MÖ9 }\end{array}$ & 3 & $\begin{array}{l}\text { “...Nova } 5000 \text { ile deney yaparken dokunmatik } \\
\text { kalem ile işlem yaparken zorlanıyordum. } \\
\text { Ekran çok hassas olmasındandı sanırım. Bir } \\
\text { kez de ekran donmuştu. Ama sistemi kolaylıkla } \\
\text { reset attı̆̆ımızda düzeldi...” (MÖ8) } \\
\text { “...Dokunmatik ekranla yazı yazmaktansa } \\
\text { bence Mouse ve klavye kullanmak işi } \\
\text { kolaylaştırır ama tabiki onları taşımakta ayrı } \\
\text { bir yük. Birde sensörler çok hassas biraz fazla } \\
\text { akım verdimi hemen sigortası atıyor...”(MÖ1) }\end{array}$ \\
\hline
\end{tabular}

Tablo 3'e göre öğretmen adaylarının mobil teknoloji ile bütünleşik sensörler ile yapılan laboratuvar uygulamaları esnasında yaşadığı sorunlar hakkındaki görüşleri incelendiğinde, "Hiçbir sorun yaşamadım (S1), Sistemi kullanabilme becerisinden kaynaklanan sorunlar (S2), 
Güç kaynağı kullanımında yaşanan sorunlar (S3), Cihaz sayısının yetersizliği (S4), Grup çalışmasından kaynaklanan sorunlar (S5), Teknik sorunlar (6)" kodlarının oluştuğu görülmektedir. İlgili kodlara ait frekans değerleri incelendiğinde, S1 kodu 3 öğretmen aday1 tarafından ifade edilirken, S2 kodu 4 öğretmen adayı tarafından, S3 kodu 2 öğretmen aday1 tarafindan, S4 kodu 5 öğretmen adayı tarafından, S5 kodun 2 öğretmen adayı tarafından ve S6 kodu ise 3 öğretmen adayı tarafından ifade edilmiştir.

\section{Yarı Yapılandırılmış Mülakatın Üçüncü Sorusuna Yönelik Bulgular}

Mülakatın üçüncü sorusunda öğretmen adaylarına "Mobil teknoloji ile bütünleşik sensörler ile yapılan laboratuvar uygulamalarının fen eğitimine katkıları hakkındaki düşünceleri nelerdir?” sorusu yöneltilmiştir. Öğretmen adaylarının vermiş olduklarını örnek cevaplar Tablo 4'de sunulmuştur.

Tablo 4. Mülakatın Üçüncü Sorusuna Verilen Öğretmen Adaylarının Cevaplar ve Frekanslar

\begin{tabular}{|c|c|c|c|c|}
\hline \multirow[t]{2}{*}{$\begin{array}{l}\text { Kod } \\
\text { No }\end{array}$} & $\begin{array}{c}\text { Fen Eğitimine } \\
\text { Katkıları }\end{array}$ & \multirow[t]{2}{*}{ Katılımcılar } & \multirow[t]{2}{*}{$\mathrm{f}$} & \multirow[t]{2}{*}{ Alint } \\
\hline & Kod & & & \\
\hline K1 & $\begin{array}{l}\text { Laboratuvar } \\
\text { korkularını azaltır }\end{array}$ & $\begin{array}{l}\text { MÖ3, MÖ4, } \\
\text { MÖ6, MÖ9 }\end{array}$ & 4 & $\begin{array}{l}\text { “...Laboratuvarda yaşayacă̆l sorunlardan } \\
\text { çekinen öğrenciler için uygun bir yöntem } \\
\text { bence...” (MÖ3) }\end{array}$ \\
\hline
\end{tabular}

\begin{tabular}{|c|c|c|c|c|}
\hline $\mathrm{K} 2$ & $\begin{array}{l}\text { Derse } \\
\text { arttırır. }\end{array}$ & $\begin{array}{l}\text { MÖ1, MÖ2, } \\
\text { MÖ3, MÖ4, } \\
\text { MÖ5, MÖ6, } \\
\text { MÖ7, } \\
\text { MÖ8,MÖ9, } \\
\text { MÖ10 }\end{array}$ & 10 & 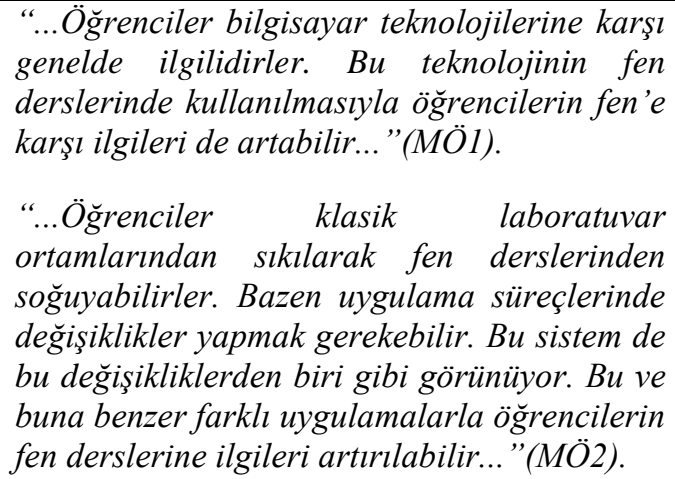 \\
\hline K3 & Özgüveni arttırır. & MÖ3, MÖ9 & 2 & $\begin{array}{l}\text { “...Grup çalışmalarında cihaz yetersizliği } \\
\text { nedeniyle bazı arkadaşların geri planda } \\
\text { kaldığını gördüm. Bu arkadaşlara cihazlar } \\
\text { kullandırıldığında ders sürecine daha aktif } \\
\text { katıldıklarını fark ettim. Bu da uygulamanın } \\
\text { bazı öğrencileriçin özgüveni artırıcı bir özellik } \\
\text { olduğunu göstermektedir. Ortaokullardaki } \\
\text { ögrenciler için de bu geçerli olacaktır diye } \\
\text { düşünüyorum...”(МÖ9). }\end{array}$ \\
\hline
\end{tabular}




\begin{tabular}{|c|c|c|c|c|}
\hline K4 & $\begin{array}{l}\text { Bilginin } \\
\text { arttırır. }\end{array}$ & $\begin{array}{l}\text { MÖ1, MÖ2, } \\
\text { MÖ3, MÖ5, } \\
\text { MÖ9, MÖ10 }\end{array}$ & 6 & $\begin{array}{l}\text { “...Deneylerin bu şekilde teknolojik aletlerle } \\
\text { yapılması ile ögrenmenin daha kalıcı olacağını } \\
\text { düşünüyorum. Çünkü bilgiye ulaşmak bu } \\
\text { sistemde daha kolay tıkandığımız noktada her } \\
\text { an internete başvura biliyoruz...” (MÖ3) } \\
\text { “..Bu dönem yaptığımız uygulamaların } \\
\text { sayesinde bazı kavramlar hafızamda yer etti. } \\
\text { Ilerde imkân olursa öğrencilerime bu sistem ile } \\
\text { deney yaptırırsam onlarında ögrendiklerini } \\
\text { unutmayacağını düşünüyorum...” (MÖ5) }\end{array}$ \\
\hline K5 & Derse katılımı sağlar. & $\begin{array}{l}\text { MÖ2, MÖ3, } \\
\text { MÖ4 MÖ6, } \\
\text { MÖ7, } \\
\text { MÖ8,MÖ9 }\end{array}$ & 7 & $\begin{array}{l}\text { “...Bu dönem dikkatimi çeken bir olay oldu. } \\
\text { Geçen döneme göre bütün arkadaşlar } \\
\text { deneylerin çoğuna katıldılar. Geçen dönem } \\
\text { isteksiz olarak geliyorduk ama işin içine } \\
\text { teknoloji girdiğinde gerçekten her deneye } \\
\text { gelmek, ögrenmek ve sonuçların ve grafiklerin } \\
\text { nasıl oluştuğunu ögrenmek istedim...” (MÖ9) } \\
\text { “...̧̧̇şin içinde bilgisayarlı sistemlerin olması } \\
\text { ders katılımı artırdı. Merak uyandırdığl için } \\
\text { sanırım. Çocuklar üzerinde de bence derse } \\
\text { katılım için büyük etkisi olacaktır. Günümüz } \\
\text { çocuklarl bilgisayar ve teknoloji } \\
\text { düş̧ünü....(MÖ6) }\end{array}$ \\
\hline
\end{tabular}

“...Biraz önce dediğim gibi bu şekilde bir öğrenme sayesinde bilginin daha kalıcı olacă̆ gibi bu aynı zamanda da anlamlı bir ögrenmeye yol açacaktır. Anlamla ögrenme Anlamlı öğrenmeyi MÖ1, MÖ3, 4 için ögrencinin motivasyonu derse ilgisinin teşvik eder. MÖ5, MÖ6 olması şart işte tam bu noktada bilgiye erişmenin en kolay yolu teknolojinin kullanımı işin işine girer ki buda bu deney sistemleri ile başarlya ulaşılır diye düşünüyorum ..." (MÖ3)

\begin{tabular}{|c|c|c|c|}
\hline K7 & $\begin{array}{l}\text { Soyut kavramların } \\
\text { somutlaştırılmasını } \\
\text { sağlar. }\end{array}$ & $\begin{array}{l}\text { MÖ3, MÖ7, } \\
\text { MÖ10 }\end{array}$ & $\begin{array}{l}\text { “...Fen dersi soyut kavramların olduğu bir } \\
\text { ders yani mesela bir manyetik alanı veya bir } \\
\text { indüksiyon akımını dolayısı ile elektriğin nasıl } \\
\text { oluştuğunu zihnimizde canlandıramaya biliriz. } \\
\text { Bu sistemdeki manyetik alan sensörü ve akım } \\
\text { sensörlerinin verileri grafiğe aktarması ile } \\
\text { oluşturulan grafiklerden bu değişkenlerin nasıl } \\
\text { değiştiklerini daha net olarak görme imkânı } \\
\text { sağladı. Özellikle indüksiyon akımını ben bu } \\
\text { zamana kadar sinüs dalgası şeklinde } \\
\text { düşünmüyordum. Belki teorik olarak alternatif } \\
\text { akım değişken akım diyordum ama grafiğini bu } \\
\text { şekilde düşünmemiştim. Birçok arkadaşımın da } \\
\text { böyle olduğunu zannediyorum. Bu açıdan çok } \\
\text { faydalı oldu...(MÖ7) }\end{array}$ \\
\hline
\end{tabular}

Tablo 4'e göre öğretmen adaylarının mobil teknoloji ile bütünleşik sensörler ile yapılan laboratuvar uygulamalarının fen eğitimine katkıları hakkındaki görüşleri incelendiğinde, “Laboratuvar korkularını azaltır (K1), Derse karşı ilgiyi arttırır (K2), Özgüveni arttırır (K3), 
Bilginin kalıcılığı arttırır (K4), Derse katılımı sağlar (K5), Anlamlı öğrenmeyi teşvik eder (K6), Soyut kavramların somutlaştırılmasını sağlar (K7), Teknolojinin ders sürecine entegrasyonunu sağlar (K8)" kodlarının oluştuğu görülmektedir. İlgili kodlara ait frekans değerleri incelendiğinde, K1 kodu 4 öğretmen adayı tarafından ifade edilirken, K2 kodu 10 öğretmen adayı tarafından, K3 kodu 2 öğretmen adayı tarafından, K4 kodu 6 öğretmen adayı tarafından, K5 kodu 7 öğretmen adayı tarafından, K6 kodu 4 öğretmen adayı tarafından ve K7 kodu ise 3 öğretmen adayı tarafından ifade edilmiştir.

\section{Yarı Yapılandırılmış Mülakatın Dördüncü Sorusuna Yönelik Bulgular}

Mülakatın dördüncü sorusunda öğretmen adaylarına "Mobil teknoloji ile bütünleşik sensörler ile yapılan laboratuvar uygulamalarının daha iyi olması için ne gibi öneriler söyleyebilirsiniz?” sorusu yöneltilmiştir. Öğretmen adaylarının vermiş olduklarını örnek cevaplar Tablo 5'de sunulmuştur.

Tablo 5. Mülakatın Dördüncü Sorusuna Verilen Öğretmen Adaylarının Cevaplar ve Frekanslar

\begin{tabular}{|c|c|c|c|c|}
\hline $\begin{array}{c}\text { Kod } \\
\text { No }\end{array}$ & Öneriler & Katılımcılar & $\mathrm{f}$ & Alınt \\
\hline P1 & $\begin{array}{l}\text { Tanıtım programlarının } \\
\text { uygulama süreci } \\
\text { uzatılmalı }\end{array}$ & $\begin{array}{l}\text { MÖ1, MÖ3, } \\
\text { MÖ6, MÖ8, } \\
\text { MÖ10 }\end{array}$ & 5 & $\begin{array}{l}\text { “...Nova } 5000 \text { kullanmak için verilen ön } \\
\text { eğitimlerin deneylere başlamadan önce çok } \\
\text { faydalı olduğunu düşünüyorum. Ama iki } \\
\text { haftadan daha fazla süre olsa daha çok örnek } \\
\text { uygulamalar yapılsa daha iyi olurdu...” } \\
\text { (MÖ1) } \\
\text { “...̇lk haftalarda verileri almak için gerekli } \\
\text { olan sensör ayarlarını yaparken çok } \\
\text { zorlandım. Bu durum bence programın tanıtımı } \\
\text { aşamasında daha yoğun pratik uygulamalar } \\
\text { yapılarak aşılabilir. Bundan dolayı } 2 \text { haftalık } \\
\text { programa uyum çalışmalarının daha uzun } \\
\text { tutulmasının olacağını } \\
\text { düşünüyorum...” (MÖ8) }\end{array}$ \\
\hline P2 & $\begin{array}{l}\text { Cihaz sayısı artırılarak } \\
\text { bireysel uygulamalara } \\
\text { da imkân tanınmalı }\end{array}$ & $\begin{array}{l}\text { MÖ1, MÖ2, } \\
\text { MÖ4,MÖ6, } \\
\text { MÖ7, MÖ8, } \\
\text { MÖ10 }\end{array}$ & 7 & $\begin{array}{l}\text { “...Keşke daha çok cihaz ve sensör olsaydl. O } \\
\text { zaman bütün arkadaşlar bireysel olarak bu } \\
\text { sistemi daha iyi tanırdılar. Nova lar az olunca } \\
\text { cihazı ele geçiren bırakmıyor. Böyle olunca da } \\
\text { diğer arkadaşlar pasif kalıyorlar...” (MÖ4) } \\
\text { “...Bence yeterli cihaz olsa en fazla iki kişi ile } \\
\text { bu deneylerin yapılması daha yararlı olurdu. } \\
\text { Böylelikle tam olarak her şeyi ile bu sistemi } \\
\text { ögrenirdik. Kendim adına tek başıma bu deney } \\
\text { sistemi ile rahatlıkla veri alabilirim ama }\end{array}$ \\
\hline
\end{tabular}




\begin{tabular}{|c|c|c|c|c|}
\hline & & & & $\begin{array}{l}\text { gruptaki bazı arkadaşların cihaza uzak } \\
\text { kalmasından dolayı tam olarak sisteme hâkim } \\
\text { olamadıklarını düşünüyorum...” (MÖ8) }\end{array}$ \\
\hline P3 & $\begin{array}{l}\text { Biyoloji ve kimya } \\
\text { deneyleri için de benzer } \\
\text { sistemler kullanılmalı }\end{array}$ & $\begin{array}{l}\text { MÖ5, MÖ6, } \\
\text { MÖ7, MÖ10 }\end{array}$ & 4 & $\begin{array}{l}\text { “...Hocamız bize sistemi tanıtırken } \\
\text { kullanacağız sensörleri tanıttı. Bunun yanında } \\
\text { elimizde mevcut olmayan başka sensörlerden } \\
\text { de bahsetti. O sensörlerin olması halinde bence } \\
\text { biyoloji laboratuvarında da kimya } \\
\text { laboratuvarında da birçok deneyin daha } \\
\text { sağlıklı yapılacă̆ını düşünüyorum. Mesela } \\
\text { bizim elimizde sıcaklık sensörü vardı bu sensör } \\
\text { ile sadece laboratuvar ortamında değil } \\
\text { dışarıda bile ölçüm alabilirdik ve sistem } \\
\text { taşınabilir olduğundan buna müsaitti. Ayrıca } \\
\text { biyolojideki fotosentez olayının bu sistemde } \\
\text { doğal ortamda rahatlıkla görebiliriz. Kimya } \\
\text { laboratuvarında da bu durum farklı sensörle } \\
\text { ile daha faydalı olarak işlenir...” (MÖ10) }\end{array}$ \\
\hline
\end{tabular}

Tablo 5'e göre öğretmen adaylarının mobil teknoloji ile bütünleşik sensörler ile yapılan laboratuvar uygulamalarının geliştirilmesine yönelik önerileri incelendiğinde, "Tanıtım programlarının uygulama süreci uzatılmalı (P1), Cihaz sayısı artırılarak bireysel uygulamalara da imkân tanınmalı (P2), Biyoloji ve kimya deneyleri için de benzer sistemler kullanılmalı (P3)" kodlarının oluştuğu görülmektedir. İlgili kodlara ait frekans değerleri incelendiğinde, P1 kodu 5 öğretmen adayı tarafından ifade edilirken, P2 kodu 7 öğretmen adayı tarafından ve P3 kodu ise 4 öğretmen adayı tarafından ifade edilmiştir.

\section{Tartışma ve Sonuçlar}

Mülakatın birinci sorusunda öğretmen adaylarından mobil teknolojik aletler ile yapılan laboratuvar uygulamaların avantaj ve dezavantajları ile ilgili görüşlerinin sorulması sonucunda Tablo 1 ve Tablo 2 'deki kodlar meydana gelmiştir. Tablo 1 incelendiğinde bu teknolojik aletlerin sağladığı en önemli avantajların 10 öğretmen adayının tamamının ortak görüşü olarak "Zamandan tasarruf sağlaması", "Daha güvenli verilere ulaş1lması", "Görsel verilerin öğrendirmeyi hızlandırması", "Hata oranın azaltılması" ve "Sistemin taşınabilir olması olmuştur. Öğretmen adaylarının görüşlerinin derinlemesine olarak incelenmesi durumunda, deney verilerin sensörler aracılığı ile kısa sürede elde edildikleri ifade edilmiştir. Elde edilen verilerin minimum hata ile görsel olarak tablolar ve grafikler halinde sunulması ile deney sonuçlarına yönelik daha çok tartışma, analiz ve yorumlama imkânları buldukları görülmüştür. Öğretmen adaylarının dikkat çektiği diğer bir avantaj ise sistemin bağımsız olarak taşınabilir 
olması olmuştur. Bu durum cihazın şarj edilebilir olmasından dolayı sadece laboratuvar ortamında değil laboratuvar dışında da farklı deney parametrelerinin ölçülebilmesine olanak tanımasından kaynaklanmaktadır. Öğretmen adaylarının görüşleri incelendiğinde, elimizde gerekli sensörlerin bulunması halinde doğa olayları ile ilgili deneylerin rahatlıkla yapılabileceği ifade edilmiştir. Öğretmen adaylarının dikkat çektiği avantajlar "Motivasyonun artırılması", "Deneylerin daha eğlenceli hale gelmesi”, "Teknolojinin derse entegrasyonu”, "Sistemin web uygulamalarını imkân tanıması" ve "Verilerin kaydedilebilmesi" olmuştur. Teknolojik aletin dezavantajları ile ilgili öğretmen adaylarının görüşleri incelendiğinde beş öğretmen adayın "Dezavantajı yoktur” cevabının olduğu görülmektedir. Mülakata dört öğretmen adayı "Öğrencileri hazırcılığa teşvik edebilir" şeklinde cevap vermiştir. Mülakat içeriklerine bakıldığında, özellikle verilerin ve grafiklerin hazır olarak sistem tarafından oluşturulmasının öğrencileri hazırcılığa itebileceğinden dolayı öğrenmeyi engelleyebileceği endişesinden kaynaklanmaktadır. Her ne kadar bu durum bir dezavantaj olarak görülse bile 5E modelinin etkili bir şekilde kullanıldığı, öğrencilerin yaparak, yaşayarak, araştıran ve sorgulayan bir öğretim modeli içerisinde bu teknolojik aletlerin kullanılmasının bu endişelerin giderilmesinde önemli bir rol oynayacağı ileri sürülebilir. Bazı sensörlerin deney esnasında yanlış kullanımdan dolayı bozulması bir öğretmen adayı tarafından bir dezavantaj olarak görülmüştür. Bu sensörle ile ölçüm alınırken üzerinden fazla akım geçirilmesi üzerine sensörün kendi mekanizmasını koruması açısından sigortasının atmasından kaynaklanmıştır. Öğretim elemanın bu durum ile ilgili gerek hizmet içi eğitim sırasında gerekse de deney esnasında ilgili uyarı yapmasına rağmen öğretmen adaylarının gerekli hassasiyeti göstermemesinden dolayı bir dezavantaj olarak görülmesine neden olduğu şeklinde yorumlanabilir. Sensörler ile ilgili olarak ileri sürülen bir diğer durum ise verilerin çok hassas olarak ölçüldüğünden dolayı gruplar arasında farklılıklar olabileceği ileri sürülmüştür. Ölçülen niceliğin farklılığından dolayı farklı ölçümlerin alınabileceğinden dezavantaj olarak değerlendirilmemesi gerektiği düşünülmektedir. Ayrıca "Kurulumunun zaman alması” şeklinde bir dezavantajın olabileceğini bazı öğretmen adayları belirtmiştir. Bu durum hizmet içi eğitimde mobil teknolojik aletin ve sensörlerin kullanımının öğrenilmesi sırasında ortadan kaldırabilir bir sorun olarak düşünülmektedir. Öğretmen adayları uygulamanın ilk haftasında aletlerin kullanımında biraz zorlanmış olmalarda ilerleyen haftalarda 5E modelinin keşfetme basamağındaki ilgili yönergeleri izleyerek deney düzeneklerini hızlı ve sorunsuz bir şekilde kurabildikleri gözlemlenmiştir. 
Mülakatın ikinci sorusu ile ilgili olarak öğretmen adaylarının mobil teknoloji ile bütünleşik sensörler ile yapılan laboratuvar uygulamaları esnasında yaşadığı sorunlar hakkındaki görüşlerini gösteren Tablo 3’ün incelenmesi neticesinde altı koddan oluşan bir yapı ortaya çıkmıştır. Bu yapı içerisinde karşımıza çıkan en büyük sorulardan birinin kişi başına düzen cihaz sayısının yetersiz olduğudur. $\mathrm{Bu}$ çalışmada beş kişiye bir NOVA 5000 düştüğünden öğrenciler bu türde görüşler bildirmişlerdir. Ayrıca dört öğrencinin gerekçe gösterdiği “Grup çalışmasından kaynaklanan sorunlar” kodunun temel gerekçesinin de cihaz yetersizliği ile ilişkili olduğu düşünülmektedir. Deney esnasında grup içerisindeki bazı öğretmen adaylarının mobil teknolojik aleti sürekli kullanmak istemeleri diğer öğretmen adaylarının pasif kalmasına neden olmuştur. Bundan dolayı grup çalışmasını benimsemeyen ve sorunlar olduğunu düşünen öğretmen adaylarının olmasına neden oluşturulmuştur. Yine ifade edilen diğer sorunlar arasında "Teknik sorunlar ve "Güç kaynağından kaynaklar sorunlar” olarak ifade edilmiştir. Bu duruma, bazı güç kaynaklarının sağlıklı çalışmamasının neden olduğu düşünülmektedir. Benzer şekilde yaşanan teknik sorunlar ise sensörlerin yanlış kullanımından dolayı kaynaklanmaktadır. Mobil teknolojik aletin ve sensörlerin kullanımına yönelik verilen hizmet içi eğitime katılmayan öğretmen adaylarının bu tip sorunları yaşadığı bilinmektedir. Sistem içerisinde kaynaklanan sorunlarda bu bağlamda değerlendirilebilir. Mülakata katılan üç öğretmen adayı ise hiçbir sorun ile karşılaşmadıklarını ifade etmektedir. $\mathrm{Bu}$ öğretmen adayları ise bütün hizmet içi eğitimlere katılmış ve mobil teknolojik aletin ve sensörlerin kullanımını benimseyerek deney esnasında etkili şekilde kullanabilen öğretmen adayları olduğu şeklinde yorumlanabilir.

Mülakatın üçüncü sorusu ile ilgili olarak öğretmen adaylarının mobil teknoloji ile bütünleşik sensörler ile yapılan laboratuvar uygulamalarının fen eğitimine katkıları hakkındaki görüşleri gösteren Tablo 4'ün incelenmesi sonucunda sekiz koddan oluşan bir yapı ortaya çıkmaktadır. Öğretmen adaylarının dikkat çektiği "Laboratuvarda deney yapamama korkularının azaltır” koduna dört aday görüş belirtmiştir. Bu durum fen eğitiminde öğrencilerin endişe ile yaklaştığı laboratuvar derslerinin etkili ve verimli geçmesi açısından mobil teknolojik aletlerin kullanımının gerekliliğini göstermektedir. Benzer şekilde “Özgüveni artırır” kodu ile ilgili görüşlerde, laboratuvar derslerinde pasif kalan öğrencilerin deneylere katılarak özgüvenlerini artırması açısından mobil teknolojik aletlerin kullanılmasının gerekliliğini göstermektedir. Genel itibari ile fen dersleri soyut kavramların çok olduğu ve öğrencilerin anlamakta güçlük çektiği bir ders olarak bilinmektedir. Bu durum fen derslerinin laboratuvarlar etkinlikleri ile desteklenerek somutlaştırılması açısından son derece önemlidir. 
$\mathrm{Bu}$ bakımdan laboratuvar derslerine karşı ilginin artırılması ve deneylerin eğlenceli hale getirilmesi gerekmektedir. Bilgisayar teknolojilerinin son dönemde hayatımızın her alanında kullanıldığı gerçeğini göz önünde bulundurduğumuzda laboratuvar çalışmalarının da teknolojik aletlerin kullanılmasının son derece faydalı olacağı düşünülmektedir. Nitekim öğretmen adaylarının görüşleri incelendiğinde bu aletlerin fen dersinde kullanılmasının derse karşı ilgiyi artıracağ1, soyut kavramları somutlaştıracağı ve teknolojinin derse entegrasyonun sağlayacağı belirtilmiştir.

Mülakatın dördüncü sorusu ile ilgili olarak öğretmen adaylarının mobil teknoloji ile bütünleşik sensörler ile yapılan laboratuvar uygulamalarının geliştirilmesine yönelik önerilerini gösteren Tablo 5'in incelendiğinde, beş öğretmen adayının hizmet içi eğitim ile teknolojik aletin ve sensörlerin tanıtımı için daha kapsamlı bir eğitim verilmesi gerektiğini önermişlerdir. Bu durum mobil teknolojik aletin ve sensörlerin kullanımına yönelik verilen hizmet içi eğitim için ayrılan iki haftalık sürenin yetersiz olduğunu ve daha kapsamlı bir hizmet içi eğitimin verilmesi gerektiğini göstermektedir. Uygulamanın ilk haftasında öğretmen adaylarının mobil teknolojik aletin ve sensörlerin kullanımında acemilik yaşadıkları görülmüş̧ür. Fakat daha sonra ki haftalarda bu sorun ortadan kalkmıştır. Genellikle bu sorunu yaşayan öğretmen adaylarının hizmet içi eğitimlere eksik katılımından kaynaklandığı düşünülmektedir. Bazı öğretmen adaylarının uygulamaların bireysel yapılması gerektiğini önermişlerdir. Bu durum deney grupların beşer kişilik olmasından ve bazı grup üyelerinin mobil teknolojik aleti sahiplenmesinden dolayı diğerlerinin mobil teknolojik aleti fazla kullanma fırsatına sahip olamamalarından kaynaklandığı düşünülmektedir. Bir diğer öneri ise bu teknolojik aletlerin diğer laboratuvar dersleri için de uygulanması gerekliliği yönündedir. $\mathrm{Bu}$ öneriden öğretmen adaylarının bu tür laboratuvar aktivitelerinden zevk aldığını göstermektedir.

\section{Öneriler}

Mobil teknolojik aletlerin ve sensörlerin kullanıldığı etkinliklerin diğer laboratuvar uygulamalarında da kullanılmasının daha faydalı olacağı düşünülmektedir. Mobil teknoloji uygulamaları ile zenginleştirilmiş etkinliklerin araştırmacılar tarafından diğer laboratuvar dersleri için de geliştirilip etkililiğinin test edilmesi önerilmektedir.

Grupların çok kalabalık olmasının teknolojik aletin kullanılmasında firsat eşitliğini ortadan kaldırması nedeni ile teknolojik aletlerin kullanıldığı çalışmalarda, grupların çok 
YYÜ Eğitim Fakültesi Dergisi (YYU Journal of Education Faculty), 2021;18(1)982-1008,http://efdergi.yyu.edu.tr,

kalabalık tutulmayarak teknolojik aletlerinin kullanımı için fırsat eşitliğinin yaratılmasına özen gösterilmesinin gerektiği önerilmektedir.

Teknolojik aletin taşınabilir olması ve şarjının uzun süre kullanılması özelliği göz önünde bulundurulduğunda laboratuvar dışı etkinliklerin yapılabilmesine olanak tanıdığından dolayı, fen doğa olayları ile ilgili ölçümlerin mobil teknoloji ile bütünleşik sensörler ile yapılması önerilmektedir.

\section{Makalenin Bilimdeki Konumu (Yeri)}

Matematik ve Fen Bilimleri Eğitimi Bölümü/Fen Bilgisi EğitimiABD / Fizik Eğitimi ABD.

\section{Makalenin Bilimdeki Özgünlüğü}

Makalede, MEB tarafından Türkiye'deki 81 ilde toplam 1473 okula toplam 1750 adet fen laboratuarı kurulması projesinde kullanılmak üzere gönderilen NOVA5000 deney setlerinin aktif olarak kullanılması için fizik laboratuvarlarına yönelik yapılandırmacı kuramın 5E modeline göre etkinler hazırlanarak uygulamasının yapılması ve sonrasında deneylerde kullanılan bu teknolojik aletler hakkında öğretmen adaylarının görüşlerinin alınmasını amaçlanmıştır. Çalışmada, mobil teknoloji ile bütünleşik sensörlerin kullanıldığı etkinlikler tasarlanmıştır. MEB, yüksek ücretler ödeyerek aldığı bu teknolojik aletlerin okullarda etkili şekilde kullanılmadığı ve kullanımına yönelik materyallerin yetersiz olduğu bilinmektedir. Bu bağlamda hem bu aletlerin kullanımına yönelik yeni etkinlikler geliştirilmesi hem de bu etkinliklerin öğretmen adaylarına hizmet öncesi uygulanması açısından önem arz etmektedir.

\section{Kaynaklar}

Açısl1, S. ve Turgut, Ü. (2011). The examination of the influence of the materials generated in compliance with 5E learning model on physics laboratory applications. International Online Journal of Educational Sciences, 3(2), 562-593.

Ambrose, B.S. (2004). Investigating student understanding in intermediate mechanics: Identifying the need for a tutorial approach to instruction. American Journal of Physics, 72(4), 453-459. 
Avcı, Ü., Kurtoğlu, M. ve Seferoğlu, S.S. (2010). Türkiye'de planlı kalkınma ve teknoloji politikaları. Akademik bilişim'10 XII. Akademik Bilişim Konferansı Bildirileri. 10-12 Şubat 2010. Muğla Üniversitesi. (465-473).

Aydın, M. Artun, H., Okur, M. ve Ürey, M. (2012). Bilgisayar destekli dijital deney araçlarının öğretmen adaylarının kavramları anlamaları üzerindeki etkisi: Sürtünmeli eğik düzlem deneyi örneği. Bayburt Üniversite Ĕ̆itim Fakültesi Dergisi, 7(1), 68-90.

Ayvacı, H. Ş., Bakırcı, H. ve Başak, M. H. (2014). Fatih projesinin uygulama sürecinde ortaya çıkan sorunların idareciler öğretmenler ve öğrenciler tarafından değerlendirilmesi. Yüzüncü Yll Üniversitesi Ĕ̈itim Fakültesi Dergisi, 11(1), 20-46.

Ayvacı, H.Ş. Özsevgeç, T. ve Aydın, M. (2004). Data logger cihazının ohm kanunu üzerindeki pilot uygulamas1. The Turkish Online Journal of Educational Technology, 3(3), 108-114.

Ayvacı, H.Ş. ve Küçük, M. (2005). İlköğretim okulu müdürlerinin fen bilgisi laboratuarlarının kullanımı üzerindeki etkileri. Milli Ĕgitim Dergisi, 165, 1-9.

Ayvacı, H. Ş., \& Yıldız, M. (2013). 5E modeline uygun olarak tasarlanan laboratuvar materyaliyle gerçekleştirilen öğretim sürecinin etkililiğinin değerlendirilmesi: Işı ğın kırılması. Bayburt Ĕ̈itim Fakültesi Dergisi, 8(1), 1-20.

Bakırcı, H., ve Kutlu, E. (2018). Fen bilimleri öğretmenlerinin FeTeMM yaklaşımı hakkındaki görüşlerinin belirlenmesi. Türk Bilgisayar ve Matematik Ĕ̌gitimi Dergisi, 9(2), 367-389.

Bal, E. (2012). 5E Modeli merkezli laboratuvar yaklaşımının fizik laboratuvarı dersinde fen bilgisi ögretmen adaylarının tutum ve başarılarına etkisi. Yayınlanmamış yüksek lisans tezi, Kastamonu Üniversitesi, Kastamonu.

Borghi, L., De Ambrosis, A., Lunati, E. \& Mascheretti, P. (2001). In service teacher education: An attempt to link reflection on physics subjects with teaching practice. Physics Education, 36(4), 299-305.

Çepni, S. ve Ayvacı, H.Ş. (2006). Laboratuvar destekli fen öğretimi yaklaşımları. Çepni, S. (Ed.) Kuramdan uygulamaya fen ve teknoloji uygulamaları (190-217). Ankara: PegemA.

Çepni, S. (2018). Introduction to research and project studies. Press (Eight Print), PegemA Publishing: Ankara.

Ekiz, D. (2020). Scientific research methods. (6thEdition), Ankara: Anı Publishing.

Güneş, H., Şener, N., Germi Topal, N. ve Can, N. (2013). Fen ve teknoloji dersinde laboratuvar kullanımına yönelik öğretmen ve öğrenci değerlendirmeleri. Dicle Üniversitesi Ziya Gökalp Ĕ̌itim Fakültesi Dergisi, 20,1-11. 
YYÜ Eğitim Fakültesi Dergisi (YYU Journal of Education Faculty), 2021;18(1)982-1008,http://efdergi.yyu.edu.tr,

Okur, M. (2014). Mobil teknolojilerin laboratuvar ortamlarında kullanılmasına yönelik rehber materyallerin geliştirilmesi ve etkililiğinin değerlendirilmesi: Genel fizik laboratuart-II örneği. Yayınlanmamış Doktora Tezi, Eğitim Bilimleri Enstitüsü, Karadeniz Teknik Üniversitesi, Trabzon.

Özdener, N. (2005). Deneysel öğretim yöntemlerinde benzetişim (simulation) kullanımı. The Turkish Online Journal of Educational Technology, 4(4), 93-98.

Pinto', R., Ferna'ndez C., Oro, J. ve Aliberas, J. (2004). Educational approach for CBL. Subwork Packadge 1.3. European project: Integrating knowledge for the use of informatics tools in science education (IKUITSE), (Contract No. HPSE-CT-200260055).

Russell D.W., Lucas K. B. \& McRobbie, C. J. (2004). Role of the microcomputer-based laboratory display in supporting the construction of new understanding in thermal physics. Journal of Research in Science Teaching, 41(2), 165-185.

Seyhan Güngör, H ve Okur, M. (2020). Fen bilimleri laboratuarlarında mobil teknoloji desteğinin önemi hakkında öğretmen görüşlerinin incelenmesi. Yüzüncü Yıl Üniversitesi Eğitim Fakültesi Dergisi, 17(1), 1242-1271.

Sönmez, E., Dilber, R., Karaman, İ. ve Şimşek, D. (2005). Fizik laboratuvarında kullanılan deney malzemeleri üzerine bir çalışma. Atatürk Üniversitesi Kazım Karabekir Ĕgitim Fakültesi Dergisi, 0 (11), 590-604.

Tanel, Z. ve Önder, F. (2010). Elektronik laboratuvarında bilgisayar simülasyonları kullanımının öğrenci başarısına etkisi: Diyot deneyleri örneği. Buca Eğitim Fakültesi Dergisi, 27, 101-110.

Yıldırım, A. ve Şimşek, H. (2013). Qualitative research methods in the social sciences. Ankara: Seçkin Publications. 


\section{Extended Abstract}

\section{Problem Statement}

The progress of countries in science and technology depends on raising individuals who are inquisitive, analytical and entrepreneurial. Raising individuals with these characteristics can be realized more easily and effectively by teaching science. In the science education process, laboratories are the environments where learning by doing and experiencing is provided (Ayvacı and Küçük, 2005). In science education, great importance should be attached to laboratory applications in order to increase students’ interest in science and to teach subjects effectively and permanently (Güneş, Şener, Germi, and Can, 2013). In parallel with this change in the world, our country is in an effort to renew its science laboratories with technological devices. Laboratories equipped with blackboards, chalk and traditional experiment equipment have gradually begun to give way to smart boards, modern experiment units and experiment sets. MoNE aims to equip every classroom and laboratory environment with smart boards, computers, projection devices and local network connections within the scope of the Movement of Enhancing Opportunities and Improving Technology (FATİH) project. In addition, MoNE has purchased mobile technological devices and sensors (such as NOVA 5000) to be used in primary and secondary education science laboratories in order to enrich the laboratory environments in its schools and to catch the latest technology (Güngör Seyhan \& Okur, 2020). These technological devices are used in the laboratory environment as well as they are actively used outside the laboratory thanks to their mobile feature, and they also have features such as recording and drawing their graphics simultaneously, such as temperature, humidity, sunlight, carbon dioxide change in nature. The use of technological tools in science laboratories is useful in teaching abstract concepts such as physics and chemistry, in terms of gaining scientific skills to students (Özdener, 2005).

In addition to purchasing all these technological test equipment to schools under the Ministry of National Education, effective use of these tools is also of great importance. The effective use of the tools in the renewed laboratory environments in teaching will be possible with the teachers getting to know these tools and gaining the necessary skills to use them. This study is important for science and technology pre-service teachers because it includes activities such as introducing systems integrated into mobile technological devices, learning the features, setting up experimental setups, and collecting and recording data with the experiment program. It is of great importance for pre-service teachers to learn the use of these technologies in the 
YYÜ Eğitim Fakültesi Dergisi (YYU Journal of Education Faculty), 2021;18(1)982-1008,http://efdergi.yyu.edu.tr,

future in order to have the skills to use these technological devices effectively in their classrooms and to develop a positive attitude towards laboratory work. When the relevant literature was examined, it was seen that the studies using the mobile technology supported $5 \mathrm{E}$ model were not at a sufficient level. In this context, it is important to develop laboratory activities using mobile technologies designed according to the $5 \mathrm{E}$ model and to evaluate their effectiveness.

\section{Purpose of the Study}

Within the scope of the study, it was applied for 6 weeks using 6 different worksheets developed by using sensors integrated with mobile technological devices according to the $5 \mathrm{E}$ model of the constructivist theory. At the end of the applications, it was aimed to get the opinions of the pre-service teachers by conducting interviews about the use of mobile technological devices in laboratory environments. In this context, the following questions were asked to the sample group. According to this;

1. What are your opinions about the advantages and disadvantages of laboratory applications made with sensors integrated with mobile technology? Please explain.

2. What kind of problems did you encounter while performing laboratory applications with sensors integrated with mobile technology? Please explain.

3. How does conducting laboratory applications with sensors integrated with mobile technology contribute to the teaching of science concepts? Please explain.

4. What would you suggest for a better execution of the laboratory application with sensors integrated with mobile technology? Please explain.

\section{Method (s)}

In this study, one of the qualitative research methods, the special case study was used. The most distinctive feature of the special case method is the in-depth examination of the subject determined by the researcher without prejudices (Ekiz, 2020). The case study is known as a research method that reveals the existing situation (Çepni, 2018). In this study, the special case method was preferred in order to reveal the experiences of the pre-service teachers as a result of using mobile technologies in the laboratory environment at the end of the application. 
The research was conducted with 32 pre-service teachers who took the General Physics Laboratory II course at Karadeniz Technical University, Fatih Faculty of Education, Department of Science Education. While the sample group participating in the study was determined according to simple random sample selection, the easily accessible sampling method was chosen among the qualitative sampling methods in the sample group in which semi-structured interviews were conducted. This sampling method is based on the principle of choosing the closest sample available to give practicality to the research (Yıldırım and Şimşek, 2013). Accordingly, semi-structured interviews were conducted with 10 easily accessible preservice teachers at the end of the applications. In the analysis process, the participants were coded as IS1, IS2, IS3, IS4, IS5, IS6, IS7, IS8, IS9, IS10.

Research data were obtained using a semi-structured interview form. Descriptive and content analysis were used in the analysis of the interviews. Content analysis is a systematic technique in which the data obtained by coding based on a certain rule is summarized with smaller content categories (Büyüköztürk, 2007). The audio recordings obtained as a result of the interviews were transcribed. At the end of the transcript, the codes were removed and the categories were created.

\section{Findings and Discussions}

According to Table 1, when the opinions of the pre-service teachers about the advantages of the laboratory applications made with sensors integrated with mobile technology are examined, it is stated that "Saving time (A1), Providing access to safer data (A2), Accelerating learning by presenting visual data (graphics, tables, diagrams, etc.) (A3), Recording data (archiving and e-portfolio) (A4), Increasing motivation (A5), Reducing error rate (A6), Being mobile (portable) of the system (A7), Ensuring the integration of technology into the course process (A8 ), Making experiments more fun (A9), System allowing web-supported applications (A10)" codes are formed. When the frequency values of the relevant codes are examined, A1, A2, A3, A6 and A7 codes are expressed by 10 pre-service teachers, A10 code by 8 pre-service teachers, A 9 code by 7 pre-service teachers, A8 code by 6 pre-service teachers, A4 code by 5 pre-service teachers and A5 code by 4 pre-service teachers.

According to Table 2, when the opinions of the pre-service teachers about the disadvantages of the laboratory applications made with sensors integrated with mobile technology were examined, the codes of "No disadvantage (D1), Encouraging students for laziness (D2), 
Sensitivity of sensors (D3), Time-consuming installation (D4)” were occurred. When the frequency values of the relevant codes were examined, D1 and D2 codes were expressed by 5 pre-service teachers, D3 code was expressed by 2 pre-service teachers and D4 code was expressed by 1 pre-service teacher.

According to Table 3, when the opinions of the pre-service teachers about the problems they experienced during the laboratory applications with sensors integrated with mobile technology are examined, "I did not have any problems (S1), Problems arising from the ability to use the system (S2), Problems in using the power supply (S3), Inadequate device numbers (S4), Problems arising from group work (S5), Technical problems (6) ". When the frequency values of the relevant codes are examined, the S1 code is expressed by 3 pre-service teachers, the S2 code by 4 pre-service teachers, the S3 code by 2 pre-service teachers, the S4 code by 5 pre-service teachers, the S5 code by 2 pre-service teachers, and the S6 code by 3 pre-service teachers.

According to Table 4, when the opinions of pre-service teachers about the contribution of laboratory applications made with sensors integrated with mobile technology to science education are examined, "It decreases laboratory anxiety (K1), It increases interest to the course (K2), It increases self-confidence (K3), It increases the permanence of knowledge (K4 ), It provides participation to the course (P5), It encourages meaningful learning (K6), It ensures concretization of abstract concepts (K7), It provides integration of technology into the course process (P8)" codes are observed. When the frequency values of the relevant codes are examined, the $\mathrm{K} 1$ code is expressed by 4 pre-service teachers, the $\mathrm{K} 2$ code by 10 pre-service teachers, the K3 code by 2 pre-service teachers, the K4 code by 6 pre-service teachers, the K5 code by 7 pre-service teachers, the K6 code by 4 prospective teachers and K7 code by 3 preservice teachers.

\section{Conclusions and Recommendations}

When Table 1 is examined, the most important advantages provided by these technological devices are "Saving time”, "Providing access to safer data”, “Accelerating 
learning by presenting visual data", "Reducing the error rate" and "The portability of the system” as the consensus of all 10 pre-service teachers. It was stated that, if the opinions of the pre-service teachers were examined in depth, the experimental data were obtained through the sensors in a short time. When the opinions of the pre-service teachers about the disadvantages of technological equipment are examined, it is seen that five pre-service teachers have the answer "There is no disadvantage". Four pre-service teachers replied to the interview as "It can encourage students to laziness". As a result of the examination of Table 3, which shows the opinions of the pre-service teachers about the problems they experienced during the laboratory applications with sensors integrated with mobile technology, a structure consisting of six codes has emerged. One of the biggest questions we encounter in this structure is that the number of regular devices per person is insufficient. Regarding the third question of the interview, a structure consisting of eight codes emerges as a result of the examination of Table 4, which shows the opinions of pre-service teachers about the contributions of laboratory applications made with sensors integrated with mobile technology to science education. Four pre-service teachers expressed their views on the code "It reduces anxiety of not being able to do experiment in the laboratory”, which attracted attention by the pre-service teachers. Regarding the fourth question of the interview, when Table 5 showing the suggestions of the pre-service teachers for the development of laboratory applications made with sensors integrated with mobile technology is examined, they suggested that a more comprehensive training should be given for the in-service training of five pre-service teachers and the introduction of technological devices and sensors.

It is thought that it will be more beneficial to use the activities where mobile technological devices and sensors are used in other laboratory applications. It is recommended that the activities enriched with mobile technology applications should be developed and tested for other laboratory courses by researchers.

It is suggested that in studies where technological tools are used, due to the fact that the groups are too crowded, it eliminates the equality of opportunity in the use of technological tools, care should be taken to create equal opportunity for the use of technological devices by not keeping the groups too crowded.

Considering the fact that the technological device is portable and its charge can be used for a long time, it is recommended to make measurements related to natural phenomena with 
YYÜ Eğitim Fakültesi Dergisi (YYU Journal of Education Faculty), 2021;18(1)982-1008,http://efdergi.yyu.edu.tr, doi:10.33711/ yyuefd.957382 Araştırma Makalesi ISSN: 1305-2020

sensors integrated with mobile technology, since it allows non-laboratory activities to be carried out. 